\title{
Teaching Research of Surveying and Mapping for Environmental Design Major
}

\author{
Qionglin Liu \\ School of Art and Design \\ Guangzhou University of Finance and Economics \\ Guangzhou, China 510320
}

\begin{abstract}
Through the teaching practice of Surveying and Mapping in the first grade of the Department of Environmental Design, this paper attempts to explore how to maximize the teaching effect of Surveying and Mapping by integrating four teaching modules: spatial interpretation, architectural knowledge, technical training and practical training tasks.
\end{abstract}

Keywords-environmental design major; modular teaching; surveying and mapping

\section{INTRODUCTION}

The Surveying and Mapping Course is a professional technical course for architecture majors in engineering colleges It belongs to the field of architectural surveying and engineering drawing. It is the graphical language of the measurer, which fully expresses the overall appearance and environmental atmosphere of the tested building.

The surveying and mapping course of art major ${ }^{1}$ is similar to the surveying and mapping course in the architectural design of architecture. ${ }^{2}$ Compared with the engineering of architectural drawing, it pays more attention to the space experience. Therefore, as the background of the art school, the Surveying and Mapping course of environmental design is aimed at cultivating the experience of students' architectural practice, truly experiencing the transformation process from the three-dimensional space of the building to the two-dimensional representation of the drawings, and thinking about the relationship between the graphic and the actual space, so as to cultivate professional literacy and feelings.

At present, many universities conform to the national education strategy and actively transform and develop into a technology-based university. The Surveying and Mapping course of environmental design is inherently comprehensive, professional, applicable and practical. How to construct a

Generally speaking, the major of fine arts and the art majors with certain requirements for fine arts are collectively referred to as the fine artsrelated major in colleges and universities all over the country. The fine artsrelated major mainly includes: painting, fine arts, fine arts education, animation, sculpture, art design, fashion design, industrial design, decorative art design, environmental art design, architectural engineering design, decorative art design, computer art design, product design, advertising design and production, multimedia design and production, etc.

Refer to Wang Jing, Thinking and Exploring the Teaching of Architectural Measurement in the Basic Building Design [J]. Wuhan: Huazhong Architecture, 2010, No. 6, p 185. teaching system and talent training mode of the Surveying and Mapping course of environmental design professional application talents in accordance with the characteristics of professional courses and the combination of school resources and teaching system has always been the theme explored by the teachers of the department. At the same time, since 2014, we have continued to reform and practice the teaching of Surveying and Mapping.

\section{THE ORIGIN AND STATUS OF THE COURSE}

The Course of Surveying and Mapping is the basic course of the Department of Environmental Design of the School of Art. In 2008, many teachers in the department planned and started teaching together. The course follows the applicationoriented talent cultivation ideas cultivated by urban design, architectural design, interior design, display design and landscape design. Due to the large number of professional subjects, the class hours of Surveying and Mapping are compressed into 48 classes, and the main content of Surveying and Mapping is interior and furniture. In the first year of the university, the course will be opened in the second semester following the course Introduction to Environmental Design and Hand-painted Performance. It is the first course of professional design and learning.

The students of the art academies are all from the candidates who have the foundation of art. They are unfamiliar with the engineering surveying and mapping. How to make the freshmen students establish a good sense of architectural space and architectural interest in a short period of six weeks, while mastering the basic knowledge of surveying and mapping and using it freely?

Since 1952, the Architectural Departments of most universities in China have offered the course Surveying and Mapping of Ancient Architecture and compiled textbooks. The surveying and mapping objects are mainly classical buildings, which is also a tribute to the ancient masters. ${ }^{3}$ For example, the School of Architecture of South China University of

The Renaissance master Alberti believes that the mapping of classic architecture is to learn from ancient masters. The Academy of Fine Arts in Paris specializes in the "Roman Awards" to support the outstanding students of the island of Rome to investigate and map the sites of monuments. This tradition has continued in the European and American countries until the beginning of the 20 th century. 
Technology opens two weeks of the ancient building cultural heritage test course; Southeast University School of Architecture 2017-2018 school year first semester mapping world heritage Ming and Qing Palace Qingshoutang courtyard and Suzhou classical garden - Canglang Pavilion; and the main practical teaching links of architecture in foreign countries such as Milan University of Technology of Italy include architectural surveying and mapping practice. This kind of teaching has many benefits but it is difficult for students in art colleges. Therefore, which suitable measurement and drawing object for students can not only meet the teaching requirements of the course, but also enrich the students 'professionalism?

\section{CONSTRUCtion OF Practical COURSE System}

Architectural Survey and Mapping can be understood as measuring the shape, size and spatial location of buildings, and drawing corresponding plane, elevation and section drawings, which is also the main content of the traditional concept and practice of ancient building surveying and mapping. Faced with the above problems, based on Professor Wang Qiheng's textbook "Surveying and Mapping of Ancient Architecture", we continue the practice of Surveying and mapping of ancient architecture. At the same time, combined with the characteristics of the department and the teaching requirements, we creatively selected Lingnan cultural and educational buildings as surveying objects. The following additions have been added to the course:

First, select a number of cultural and educational buildings on the campus as measured objects, and each group (3-4 people) is responsible for measuring a building. plan.

Second, each group increases the actual work of the general

Third, each group makes building model based on its own measured documents.

Fourth, publicly evaluate each group of measured texts and architectural models.

These four points are countermeasures for the current problems in the Surveying and Mapping course (Table I), in which several countermeasures can solve several problems at the same time, they jointly build the basic framework of the teaching system.

TABLE I. LIST OF PROBLEMS AND COUNTERMEASURES FOR SURVEYING AND MAPPING COURSES

\begin{tabular}{|c|l|l|l|}
\hline & Problem & \multicolumn{1}{|c|}{ Countermeasures } & \multicolumn{1}{c|}{ Benefit } \\
\hline 1 & Develop interest & $\begin{array}{l}\text { Survey } \\
\text { Campus buildings }\end{array}$ & $\begin{array}{l}\text { Campus buildings are educational buildings built in the 1980s or 1990s. They are 7-9 storeys } \\
\text { with a single area ranging from 50m to 90m. Through the actual measurement of these } \\
\text { buildings, we can familiarize, understand and explore the characteristics and techniques of } \\
\text { campus buildings in Lingnan area at the end of last century. }\end{array}$ \\
\hline 2 & $\begin{array}{l}\text { Understanding of } \\
\text { architectural space }\end{array}$ & $\begin{array}{l}\text { Architectural drawing: } \\
\text { General layout }\end{array}$ & $\begin{array}{l}\text { With the emphasis on the spirit of the place in contemporary architecture, students are also } \\
\text { encouraged to recognize the site, location, and street space, and increase and focus on the } \\
\text { contents of the general layout. }\end{array}$ \\
\hline 3 & $\begin{array}{l}\text { Transformation of } \\
\text { architectural } \\
\text { drawings } \\
\text { architectural space }\end{array}$ & Model making & $\begin{array}{l}\text { The actual measurement is the transformation from the physical object to the drawing. } \\
\text { Through the conversion experience of the drawing to the scaled-down building model, it can } \\
\text { not only check the flaws of the actual measurement process, but also explore, identify, } \\
\text { discover and evaluate the measured building. }\end{array}$ \\
\hline 4 & \begin{tabular}{l} 
Spirit of teamwork \\
\cline { 2 - 3 } Develop interest
\end{tabular} & $\begin{array}{l}\text { Evaluating the works of each group of students in the class will help promote and increase the } \\
\text { enthusiasm and learning pleasure of the students. It will also increase the joy of pure actual } \\
\text { measurement learning. }\end{array}$ \\
\hline
\end{tabular}

\section{Practice of OptimizING TEAChING Mode}

In teaching practice, how to organize students to participate in teaching activities, how to open a door to surveying and mapping for students in 48 class hours, guide and stimulate professional interest of students, the organizational form is particularly important. In practice, in view of 26-30 students in each class, these first-year students lack basic architectural knowledge. Team work is the best form of work to accomplish such a huge amount of tasks in eight weeks. The whole class is divided into a group of 3-4 students, each class can have 8-10 groups, each group of students choose their favorite building monomers, and carry out the actual measurement, drawing and model making work.

For a large amount of tasks, it is necessary to have a corresponding curriculum knowledge system to support. According to the characteristics of the "modular teaching method", these knowledge systems have been reorganized and merged according to the capabilities of the seven task books into four major modules: spatial interpretation, architectural knowledge, technique training, and practical training tasks. Each knowledge point has been transformed into a task book oriented ability system. Promote the integration and modularization of course content, and highlight the applicability and practicality of the course in "Table II". 
TABLE II. COURSE SYSTEM OF SURVEYING AND MAPPING

\begin{tabular}{|c|c|c|c|c|c|c|}
\hline & Module 1 & Module 2 & Modul & & Module & \\
\hline Week & $\begin{array}{l}\text { Spatial } \\
\text { interpretation }\end{array}$ & Architectural knowledge & $\begin{array}{l}\text { Weekly training } \\
\text { assignment book }\end{array}$ & $\begin{array}{l}\text { Review drawing } \\
\text { (each group) }\end{array}$ & Technical training & $\begin{array}{l}\text { Mapping } \\
\text { specification }\end{array}$ \\
\hline 1 & \multirow{3}{*}{$\begin{array}{l}\text { External space } \\
\text { design }\end{array}$} & $\begin{array}{l}\text { General Plane Surveying } \\
\text { and Mapping Knowledge }\end{array}$ & $\begin{array}{l}\text { General Plane Surveying } \\
\text { and Mapping }\end{array}$ & No & Engineering word 1 & \multirow{2}{*}{$\begin{array}{l}\text { Architectural } \\
\text { Drawing } \\
\text { Specification } 1\end{array}$} \\
\hline 2 & & $\begin{array}{l}\text { First floor plan mapping } \\
\text { knowledge }\end{array}$ & $\begin{array}{l}\text { First floor plan } \\
\text { Surveying and Mapping }\end{array}$ & General Plane & Engineering word 2 & \\
\hline 3 & & $\begin{array}{ll}\text { Facade } & \text { surveying } \\
\text { knowledge } 1 & \end{array}$ & $\begin{array}{l}\text { South facade Surveying } \\
\text { and Mapping }\end{array}$ & First floor plan & Engineering line 1 & $\begin{array}{l}\text { Architectural } \\
\text { Drawing } \\
\text { Specification } 2\end{array}$ \\
\hline 4 & \multirow{4}{*}{$\begin{array}{l}\text { Architectural } \\
\text { space theory }\end{array}$} & $\begin{array}{ll}\text { Facade } & \text { surveying } \\
\text { knowledge } 2 & \end{array}$ & $\begin{array}{l}\text { West (East) facade } \\
\text { Surveying and Mapping }\end{array}$ & South facade plan & Engineering line 2 & $\begin{array}{l}\text { Architectural } \\
\text { Drawing } \\
\text { Specification } 2\end{array}$ \\
\hline 5 & & $\begin{array}{l}\text { Profile } \\
\text { Knowledge }\end{array}$ & $\begin{array}{lcc}1-1 & \text { Profile } & \text { Surveying } \\
\text { and Mapping } & \end{array}$ & $\begin{array}{l}\text { West(East) facade } \\
\text { plan }\end{array}$ & Copying and Drawing & \multirow{3}{*}{$\begin{array}{l}\text { Architectural } \\
\text { Drawing } \\
\text { Specification } 3\end{array}$} \\
\hline 6 & & & $\begin{array}{lrl}2-2 & \text { Profile } & \text { Surveying } \\
\text { and Mapping } & \\
\end{array}$ & 1-1 Profile plan & $\begin{array}{l}\text { of small Kestaental } \\
\text { Buildings }\end{array}$ & \\
\hline 7 & & $\begin{array}{l}\text { CAD Computer Drawing } \\
\text { Techniques. Knowledge of } \\
\text { Model Making }\end{array}$ & Model Making & 2-2 Profile plan & $\begin{array}{l}\text { Comments on Drawing } \\
\text { Copy of Small } \\
\text { Residential Buildings }\end{array}$ & \\
\hline 8 & \multicolumn{6}{|c|}{ Summary of surveying and drawing papers, Building models, Public review } \\
\hline
\end{tabular}

\section{IMPLEMENTATION EFFECTIVENESS}

Through the practice of surveying and mapping campus buildings in groups, students learn to pay attention to the building itself and the actual construction environment; through the practice of making models based on surveying and mapping, students are trained to think about the relationship between graphics and real space, especially the transformation between scale model and entity; through the actual surveying and mapping of buildings, students' architectural drawing ability is improved; through the interpretation, discussion and space experience of architectural space works, students began to pay attention to the essence of architectural design - space.

The form of teamwork not only emphasizes the independent working ability of the students, but also requires the members to work together to complete the group project, which not only increases the friendship among the students, but also promotes the overall progress of the team. The course teaching emphasizes the method-based measurement process, combined with classroom counseling and regular review, and the results are remarkable. (See "Fig. 1", "Fig. 2", "Fig. 3", and "Fig. 4").

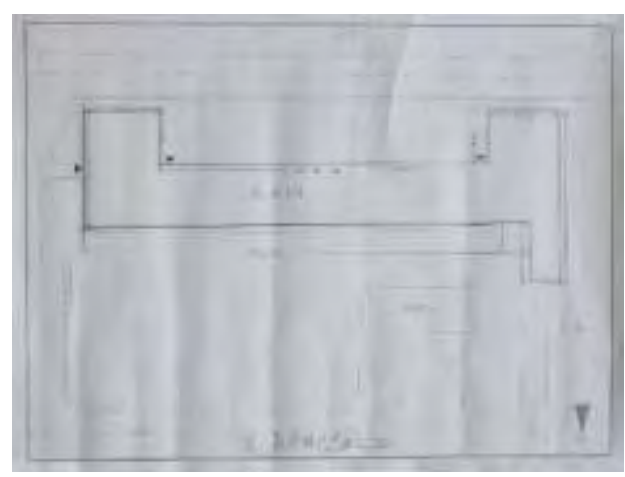

Fig. 1. Surveying drawing - general plan of the teaching building.

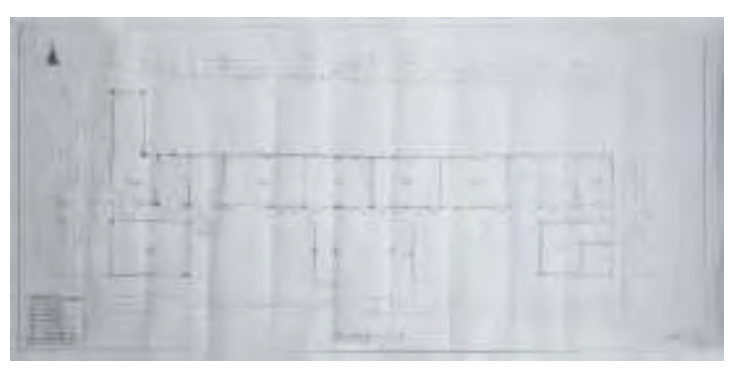

Fig. 2. Surveying drawing - first floor plane of the teaching building.

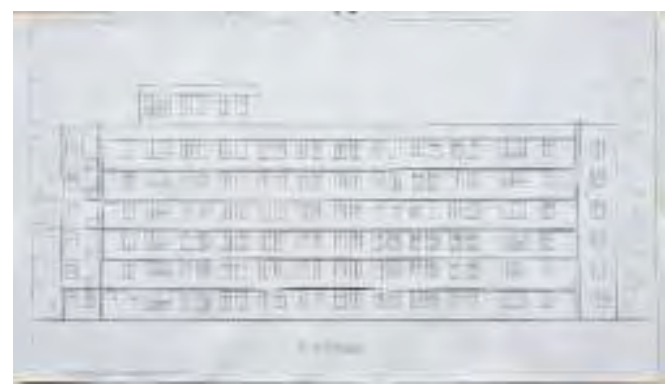

Fig. 3. Surveying drawing - south elevation of teaching building.

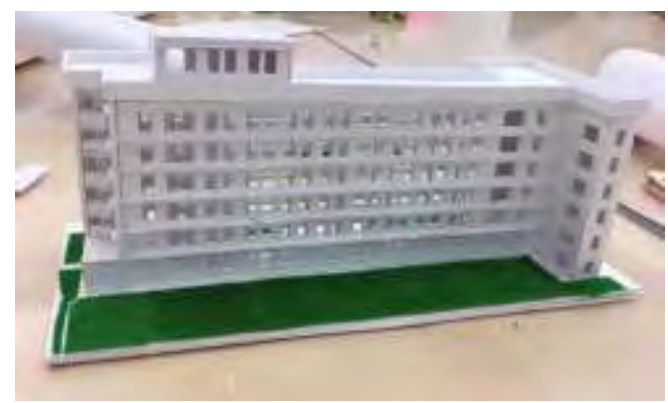

Fig. 4. Building Model of Teaching Building 


\section{CONCLUSION}

Applied technology universities are the training ground for high-level applied talents in China's economic and social development. Its goal is to cultivate high-quality applied talents with strong social adaptability and competitiveness. Therefore, focusing on cultivating practical ability and competitiveness of students is the key to building a teaching curriculum in the future.

In recent years, major colleges and universities are carrying out teaching reforms to improve the professional skills and design literacy of first-year students, and to link up with the senior Architectural Thematic Design. Through the exploration of the teaching of the Surveying and Mapping course in the first-year environmental design major, creatively optimize the teaching model and teaching content, and set up a teaching system and talent training model for the Surveying and Mapping course that is suitable for the training of applied talents in the environmental design specialty of the Academy of Arts, to meet the needs of local economic and social development and meet the needs of the construction of Chinese cultural power.

\section{REFERENCES}

[1] Wang Qiheng, Surveying and Mapping of Ancient Buildings [M]. Beijing: China Building Industry Press, 2006. (in Chinese)

[2] Zhang Yan, Architectural Engineering Drawing [M]. Beijing: China Building Industry Press, 2013. (in Chinese)

[3] Ministry of Housing and Urban-Rural Development of the People's Republic of China, General Administration of Quality Supervision, Inspection and Quarantine of the People's Republic of China, Unified Standard for Building Construction Drawing [M]. Beijing: China Building Standard Design and Research Institute, 2010. (in Chinese)

[4] Kang Jian, Liu Songyu, Architectural Education - Teaching System of the School of Architecture, University of Sheffield, UK [M]. Beijing: China Building Industry Press, 2007. (in Chinese)

[5] Zhou Xiaoyan, Wang Yuan. Discussion on the Reform of Teaching Model of Architectural Drawing Course[J]. Beijing: Science and Technology Information, 2013, 5:292. (in Chinese) 